\title{
Design and Operation of Empirical Manganese-Removing Bioreactors and Integration into a Composite Modular System for Remediating and Recovering Metals from Acidic Mine Waters
}

\author{
Ana Laura Santos $1, *$ (D) and D. Barrie Johnson 1,2 \\ 1 School of Natural Sciences, Bangor University, Bangor LL57 2UW, UK; d.b.johnson@bangor.ac.uk \\ 2 Faculty of Health and Life Sciences, Coventry University, Coventry CV1 5FB, UK \\ * Correspondence: ana.santos@bangor.ac.uk; Tel.: +44-1248-382832
}

Citation: Santos, A.L.; Johnson, D.B. Design and Operation of Empirical Manganese-Removing Bioreactors and Integration into a Composite Modular System for Remediating and Recovering Metals from Acidic Mine Waters. Appl. Sci. 2021, 11, 4287. https://doi.org/10.3390/app11094287

Academic Editor: Sebastien Farnaud

Received: 30 March 2021

Accepted: 5 May 2021

Published: 10 May 2021

Publisher's Note: MDPI stays neutral with regard to jurisdictional claims in published maps and institutional affiliations.

Copyright: (C) 2021 by the authors. Licensee MDPI, Basel, Switzerland. This article is an open access article distributed under the terms and conditions of the Creative Commons Attribution (CC BY) license (https:// creativecommons.org/licenses/by/ $4.0 /)$.

\begin{abstract}
Packed bed bioreactors were used to remove soluble manganese from a synthetic mine water as the final stage of an integrated bioremediation process. The synthetic mine water had undergone initial processing using a sulfidogenic bioreactor $(\mathrm{pH} 4.0-5.5)$ which removed all transition metals present in elevated concentrations $(\mathrm{Cu}, \mathrm{Ni}, \mathrm{Zn}$ and $\mathrm{Co})$ apart from manganese. The aerobic bioreactors were packed with pebbles collected from a freshwater stream that were coated with black-colored, Mn(IV)-containing biofilms, and their capacity to remove soluble Mn (II) from the synthetic mine water was tested at varying hydraulic retention times (11-45 h) and influent liquor $\mathrm{pH}$ values (5.0 or 6.5). Over $99 \%$ of manganese was removed from the partly processed mine water when operated at $\mathrm{pH} 6.5$ and a HRT of $45 \mathrm{~h}$. Molecular techniques (clone libraries and T-RFLP analysis) were used to characterize the biofilms and identified two heterotrophic Mn-oxidizing microorganisms: the bacterium Leptothrix discophora and what appears to be a novel fungal species. The latter was isolated and characterized in vitro.
\end{abstract}

Keywords: manganese; bioremediation; acid mine drainage; Mn-oxidizing microorganisms

\section{Introduction}

Manganese is the second most abundant transition metal in the lithosphere after iron. It occurs between 0.002 and $10 \%$ (by weight) in terrestrial ecosystems and it is also present in variable concentrations in aquatic environments and often in relatively high amounts in streams draining coal and metal mines. Manganese is found in more than 100 naturally occurring minerals either as a major component, such as in oxides, carbonates and silicates or as a minor component, such as ferromagnesian minerals and micas. Manganese oxides (including oxides, hydroxides and oxy-hydroxides) are reactive mineral phases that play an important role in biogeochemical cycling of a number of other elements [1]. Manganese can occur in several different oxidation states, though Mn (II), Mn (III) and Mn (IV) are the most commonly found in nature. The $\mathrm{MnO}_{2}(\mathrm{~s}) / \mathrm{Mn}$ (II) couple (redox potential $+1.224 \mathrm{~V}$ at $\mathrm{pH} 7$; [2]) is strongly electro-positive and Mn (IV) is one of the strongest oxidants found in natural environments and can participate in a wide range of redox reactions with organic and inorganic chemical species and compounds [3].

Biological oxidation of $\mathrm{Mn}$ (II) and formation of solid phase $\mathrm{MnO}_{2}$ is catalyzed by some prokaryotic and eukaryotic microorganisms, and some species of mixotrophic bacteria can use the energy from this reaction to support their growth [1]. Bacterial chemolithoautotrophy via manganese oxidation has been a matter of controversy for many decades and proof of this metabolism has been difficult to obtain [1]. More recently, Yu and Leadbetter [4] reported a coculture of two microbial species enriched from a municipal water distribution network in California, USA, that exhibited exponential growth dependent on Mn (II) oxidation. Comprehensive molecular, physiological and isotopic analyses suggested that biomass growth was dependent on Mn (II) oxidation. Manganese-oxidizing bacteria 
are widely distributed in natural environments and belong to several phyla including Firmicutes, Actinobacteria, Bacteroidetes and Proteobacteria [5]. A number of Mn (II)-oxidizing fungal species belonging to the phyla Ascomycota and Basidiomycota have also been described [6].

Manganese (II) is soluble within a wide $\mathrm{pH}$ range and its occurrence in surface water and groundwater can be problematic due to some of its undesirable effects on human health if ingested in high concentrations and on domestic water supplies when it is oxidized to Mn (IV) (e.g., by obstructing water distribution networks). As with many other transition metals, manganese can occur in elevated concentrations in coal and metal mine wastewaters and its removal from these sources is also desirable since, in addition to iron and aluminum, manganese hydrolysis contributes to the total mineral acidity of mine waters [7].

Manganese has some chemical features that make its removal from wastewaters sometimes costly and impractical [1,7,8], including: (i) abiotic oxidation of Mn (II) to insoluble $\mathrm{Mn}(\mathrm{IV})$ requires elevated $\mathrm{pH}(>8)$, and often large amounts of alkaline material (such as lime; $\mathrm{CaO}$ ) are required to achieve this; (ii) biological Mn (II) oxidation does not proceed rapidly in presence of Fe (II), and therefore it is not removed efficiently using aerobic wetlands where Fe (II) concentration can exceed $1 \mathrm{mg} \mathrm{L}^{-1}$ and (iii) the relatively large solubility of its sulfide phase (log Ksp of -13.3 at $25^{\circ} \mathrm{C}$; [8]) means that, unlike transition metals such as copper and zinc, it is not effectively removed in compost wetlands and sulfidogenic bioreactors. However, aerobic packed bed bioreactor systems colonized by $\mathrm{Mn}$ (II)-oxidizing microorganisms have demonstrated the biological removal of soluble Mn (II) from synthetic media [7] and mine waters [9].

Santos and Johnson [10] developed a bioremediation process to both recover base metals and mitigate a synthetic, moderately acidic and metal-rich mine water based on the chemistry of that in a working copper mine in northern Brazil. The mine water contained $7.5 \mathrm{mM}$ copper and lower concentrations $(<0.25 \mathrm{mM})$ of other transition metals $(\mathrm{Zn}, \mathrm{Ni}, \mathrm{Co}$ and $\mathrm{Mn}$ ), and had a $\mathrm{pH}$ of 5.0. The process used a single low $\mathrm{pH}$ continuous flow packed bed anaerobic sulfidogenic reactor. Excess $\mathrm{H}_{2} \mathrm{~S}$ produced by the bioreactor was delivered to an off-line vessel containing the synthetic mine water, removing $>99 \%$ copper (as $\mathrm{CuS}$ ) and causing the $\mathrm{pH}$ to fall to 2.1, precluding the formation of other metal sulfides that have larger solubility products. The partly processed mine water was then fed into the sulfidogenic bioreactor (which was maintained at $\mathrm{pH}$ 4.0-5.0) where zinc, nickel and cobalt were precipitated, again as sulfides. Soluble manganese remained in the effluent liquor throughout the process, at $\sim 150 \mu \mathrm{M}$, and therefore the liquor that drained the sulfidogenic bioreactor is referred to below as "partly processed synthetic mine water".

In order to complete the mitigation of this mine water (which could serve as a model for many others), an aerobic bioreactor packed with naturally occurring Mn (IV)-coated pebbles has been commissioned and integrated into the system. This was designed to both effectively remove soluble $\mathrm{Mn}$ and minimize the requirement for alkali addition. Molecular techniques were used to examine the indigenous microbial populations of the Mn (IV)biofilm-colonized pebbles and a Mn (II)-oxidizing fungal species that was isolated from the bioreactor during the time it was used to remediate the mine water was characterized.

\section{Materials and Methods}

\subsection{Commissioning and Operation of $\mathrm{Mn}(\mathrm{II})$-Oxidizing Bioreactors ( $\mathrm{MnOBs}$ )}

Small pebbles $(1.5-5.0 \mathrm{~cm}$ in diameter) covered with thin black coatings (Supplementary Figure S1) were collected from a catchment stream ( $\mathrm{pH}$ 6.5, containing $\sim 30 \mu \mathrm{M}$ soluble manganese) located in the Snowdonia National Park, North Wales, UK (GPS coordinates: $53^{\circ} 11^{\prime} 51.5112^{\prime \prime} \mathrm{N}, 4^{\circ} 7^{\prime} 39.7596^{\prime \prime} \mathrm{W}$ ), and stored in plastic bottles at $4{ }^{\circ} \mathrm{C}$ until use. Mariner et al. [11] have previously shown that the coatings on similar pebbles contained Mn (IV) by positive reaction with hydrogen peroxide. The pebbles were packed into 32.0 by $6.8 \mathrm{~cm}$ Perspex ${ }^{\circledR}$ columns to a depth of $24.5 \mathrm{~cm}$ (Figure 1), and partly processed synthetic mine water $(\sim 600 \mathrm{~mL})$ was added, to $3.5 \mathrm{~cm}$ above the pebbles, giving the column bioreactor a working volume of $1.02 \mathrm{~L}$. The partly processed synthetic 
mine water (pH 5.0) was that draining the sulfidogenic bioreactor in the integrated system (Supplementary Figure S2; [10]) and was adjusted, in some cases, to $\mathrm{pH} 6.5$ by adding sodium hydroxide. Nonsterile atmospheric air was bubbled (at $\sim 1 \mathrm{~L} \mathrm{~min}^{-1}$ ) into the packed bed bioreactors through an air stone, influent liquor was pumped into its base through an L-shaped Perspex ${ }^{\circledR}$ tube and drained via a fixed tube attached to the top of the columns, which maintained the reactors at a fixed volume. The systems were operated in continuous flow mode at flow rates ranging between 23 and $92 \mathrm{~mL} \mathrm{~h}^{-1}$ (equivalent to hydraulic retention times (HRTs) of $\sim 45$ and $\sim 11 \mathrm{~h}$, respectively) at $30^{\circ} \mathrm{C}$. A sampling port was connected to the outlet of each bioreactor.

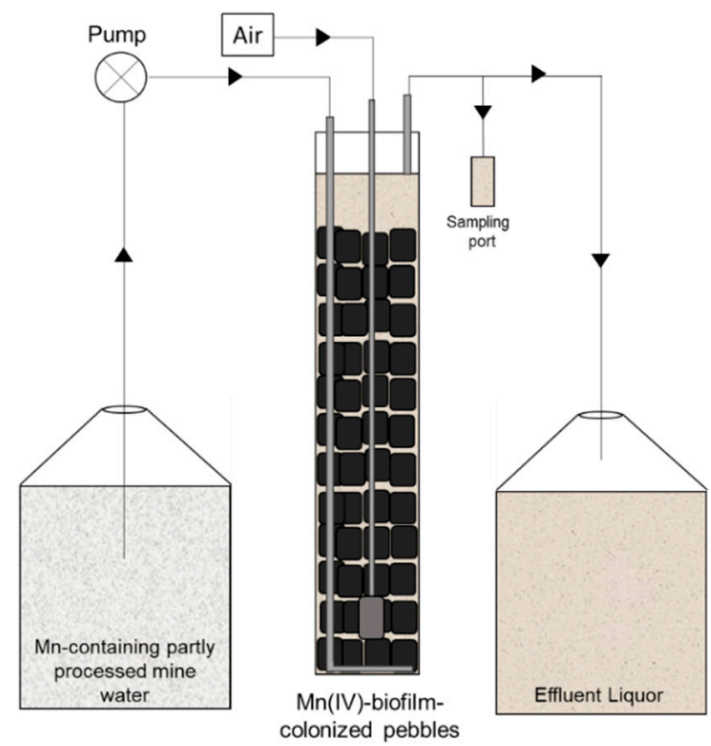

Figure 1. Schematic representation of the aerobic Mn (II)-oxidizing bioreactor. Mn-containing partly processed synthetic mine water was pumped into the bottom of the column, drained at the top and collected into an effluent bottle.

Variations in Operational and Set Up Conditions of MnOBs

The packed bed bioreactors were tested in four experimental phases over 264 days in order to determine optimum conditions for removal of manganese from the partly processed synthetic mine water. Phases C1, C2a and C2b used a single-column system (Figure 1) and evaluated how this was impacted by variations in feed liquor $\mathrm{pH}$ and HRT. In phase $\mathrm{C} 1$, the bioreactor was packed with biofilm-colonized pebbles and the partly processed synthetic mine water ( $\mathrm{pH}$ 5.0) that drained the sulfidogenic bioreactor was used directly as the influent liquor. A new column was commissioned in phase $\mathrm{C} 2$, and the $\mathrm{pH}$ of the feed liquor was adjusted to 6.5 with $\mathrm{NaOH}$ (the $\mathrm{pH}$ of the stream from which the pebbles were collected). This column was prepared as before but had a thin layer $(\sim 6 \mathrm{~cm})$ of pale-colored inert gravel (average diameter: $1.0 \mathrm{~cm}$ ) placed between two layers of biofilmcoated pebbles in order to visualize to what extent, if any, fresh rock surfaces became coated with dark-colored biofilms over the course of the experiment (Supplementary Figure S3). Phase C3 used an in-line two-column system (Supplementary Figure S4), where effluent liquor from the first packed bed bioreactor was pumped into the base of a second column. Sampling ports were attached to the drain points of the column to analyze the chemistry of water draining each bioreactor. In phase C3, the first column was that used in phase C2, while the second was a third newly commissioned backed bed bioreactor. Table 1 lists the different operational parameters used in each of the experimental phases. 
Table 1. Variations (average and standard deviation) in feed liquor $\mathrm{pH}$, flow rates, HRT and duration of each phase of the MnOBs. In phase C3, the feed liquor pH was that pumped into the first column.

\begin{tabular}{ccccc}
\hline Phases & Feed Liquor $\mathbf{p H}$ & Flow Rate $\left(\mathbf{m L ~ h}^{\mathbf{- 1}}\right)$ & HRT $\mathbf{( h )}$ & Duration (Days) \\
\hline C1 & $5.0 \pm 0.3$ & $92.0 \pm 9.7$ & $11.3 \pm 1.1$ & 126 \\
C2a & $6.5 \pm 0.3$ & $92.0 \pm 8.0$ & $11.3 \pm 1.3$ & 28 \\
C2b & $6.5 \pm 0.3$ & $44.0 \pm 2.0$ & $23.6 \pm 1.6$ & 32 \\
C3 & $6.5 \pm 0.3$ & $23.0 \pm 3.0$ & $45.2 \pm 3.5$ & 78 \\
\hline
\end{tabular}

\subsection{Biomolecular Analysis of the Microbial Biofilm Communities}

Biofilm samples were scraped off representative pebbles taken from the stream using a sterile spatula, and DNA extracted using PowerSoil Ultraclean Microbial DNA Isolation Kits (MoBio, CA, USA). Amplification of $16 \mathrm{~S}$ and $18 \mathrm{~S}$ rRNA genes was performed using 27F and 1482R primers for bacteria [12], 20F and 915R for archaea [13] and EukF and EukR for eukaryotes [11] (Supplementary Table S1). Terminal restriction enzyme fragment length polymorphism (T-RFLP) analysis of amplified genes [10] was carried out to assess the microbial diversity of biofilms on the pebbles sampled from the stream (C0) and also of those on representative pebbles at the end of phases C1, C2a and C3 of operating MnOBs. Clone libraries were constructed to identify bacterial, archaeal and eukaryotic compositions of biofilms on pebbles collected from the stream [14]. Theoretical T-RFs of the clones were obtained by measuring the length of the bacterial $16 \mathrm{~S}$ and eukaryote $18 \mathrm{~S}$ rRNA genes fragment cleaved with the restriction enzyme HaeIII.

\subsection{Identification and Characterization of a Putative Mn (II)-Oxidizing Fungus}

A solid medium was prepared containing $500 \mu \mathrm{M}$ manganese sulfate, $0.1 \mathrm{~g} \mathrm{~L}^{-1}$ yeast extract, basal salts and trace elements [15] adjusted to $\mathrm{pH} 6.5$ and gelled with $0.5 \%(w / v)$ agarose (Sigma Type I). Plates were streak-inoculated with biofilm material scraped of the black pebbles suspended in sterile water, incubated at $30{ }^{\circ} \mathrm{C}$ and inspected at regular intervals. A fungal colony (coded MnI1) that was abundant on the Mn (II) plates and which was stained brown/black (indicative of deposition of Mn (IV); Supplementary Figure S5) was purified by repeated single colony isolation and maintained on solid media and in liquid media that had the same chemical composition. The fungus isolate was then subjected to phylogenetic and physiological characterization.

\subsubsection{Biomolecular Analysis of Isolate MnI1}

The 18S rRNA gene of the fungal isolate was amplified, sequenced and compared with the GenBank database. Phylogenetic analysis was performed using Clustal X version 2.0 for sequence alignments and imported to the tree drawing software NJplot version 2.3. Sequences were trimmed manually to the length of the shortest sequence in Clustal $\mathrm{X}$ for a complete alignment. Phylogenetic trees were built by performing bootstrapped $(\times 1000)$ maximum likelihood, maximum parsimony and neighbor-joining analysis.

\subsubsection{Physiological Characteristics of Isolate MnI1}

\section{Mn (II) Oxidation}

The ability of isolate MnI1 to oxidize Mn (II) to Mn (IV) was tested in the liquid medium described above together with non-inoculated controls (in duplicate). Oxidation of manganese was assessed at regular intervals by monitoring changes in culture $\mathrm{pH}$ and measuring changes in concentrations of soluble Mn.

\section{Effects of $\mathrm{pH}$ and Temperature on Growth of Isolate MnI1}

To determine the effect of $\mathrm{pH}$ on growth of isolate MnI1, the temperature was maintained at $30^{\circ} \mathrm{C}$ and initial $\mathrm{pH}$ was set at values between 4.0 and 8.0. Portions of fungal hyphae were transferred from the plate using a sterile wire loop into flasks and macroscopic growths were monitored for a period of 10 days. To determine the effect of temperature 
on the growth of the isolate, the initial $\mathrm{pH}$ of the culture was set at 6.5 and temperatures varied between 15 and $45^{\circ} \mathrm{C}$. Growth was assessed semiquantitatively by visual inspection of the cultures.

\section{Growth on Various Organic Substrates}

Tests for growth of isolate MnI1 on different organic substrates was carried out by subculturing the fungus in yeast extract-free standard liquid medium, amended with various organic compounds (Supplementary Table S2). Different concentrations of substrates were used to approximately equalize their carbon equivalents ( $5 \mathrm{mM}$ for $\mathrm{C} 6$ substrates, $10 \mathrm{mM}$ for C3 substrates, etc.). Replicate flasks containing $5 \mathrm{~mL}$ of test medium were inoculated and incubated in an orbital shaker at $30^{\circ} \mathrm{C}$. Growth was determined by observing macroscopic growth after 10 days and comparing with those obtained in both negative controls (no organic substrate added) and positive controls containing $0.1 \mathrm{~g} \mathrm{~L}^{-1}$ yeast extract.

\subsection{Miscellaneous Analytical Techniques}

$\mathrm{pH}$ was measured using a pHase combination glass electrode coupled to an Accumet $50 \mathrm{pH}$ meter. Planktonic cells in culture samples were enumerated using a Thoma counting chamber and a Leitz Wetzlar 766200 phase contrast microscope at $\times 400$ magnification. Soluble manganese concentrations were determined using a modified formaldoxime colorimetric method [16]. Dissolved organic carbon (DOC) was measured using a Protoc Analyzer (Pollution and Process Monitoring, London, UK).

\section{Results}

\subsection{Removal of Soluble Mn from Partly Processed Mine Water Using the MnOBs}

The effectiveness of the MnOBs in removing soluble manganese from partly processed synthetic mine water is shown in Figure 2. In phase C1, during which the influent liquor was that draining the sulfidogenic bioreactor with no $\mathrm{pH}$ adjustment (Table 1) and the HRT was maintained at $\sim 11 \mathrm{~h}$, removal of soluble Mn decreased from 80 to $10 \%$ within the first 30 days of operating the packed bed bioreactor. This was followed by an increase of up to $55 \%$ (by day 40), though there was considerable variation in the performance of this $\mathrm{MnOB}$, which lasted for a total of 126 days. Water draining this $\mathrm{MnOB}$ was more acidic than the influent liquor, varying between $\mathrm{pH} 4.1$ and 5.6 (Figure 3).

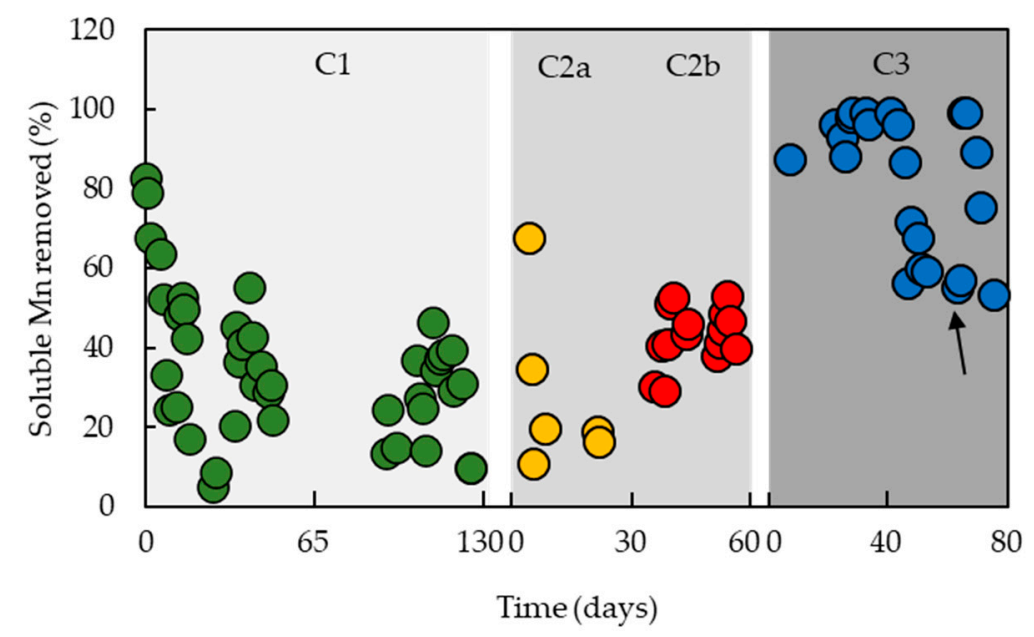

Figure 2. Variations in the percentage of manganese removed during the time course of the experiment. Key: phase C1 (green): 1-column system pH 5.0, HRT 12 h; C2a (yellow): 1-column system pH 6.5, HRT 12 h; C2b (red) 1-column system pH 6.5, HRT 24 h and C3 (blue): 2-column system $\mathrm{pH} 6.5$, HRT $45 \mathrm{~h}$. The arrow indicates where yeast extract (final concentration $100 \mathrm{mg} \mathrm{L}^{-1}$ ) was added to the influent liquor. 


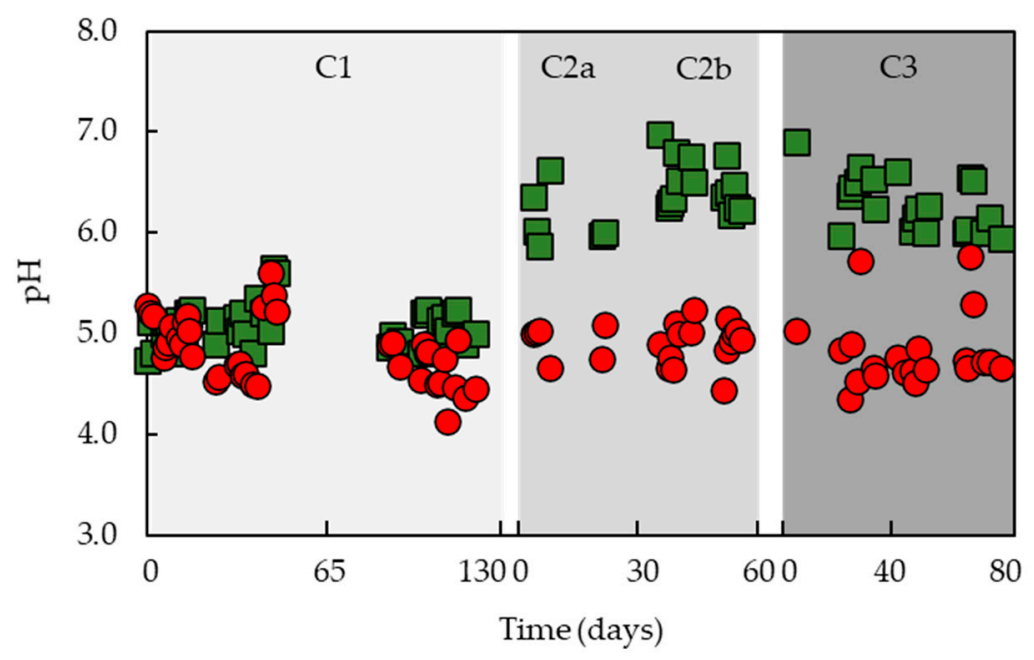

Figure 3. Differences in $\mathrm{pH}$ in the feed liquor $(\square)$ and effluent liquor $(\bullet)$ of the MnOBs. Phases $\mathrm{C} 1$ and C2a,b, 1-column system; phase C3: in-line 2-column system. The $\mathrm{pH}$ values of the effluent in phase $\mathrm{C} 3$ are those of liquors draining the second in-line column.

To test whether the reduction in the efficiency of the MnOB used in $\mathrm{C} 1$ was due to the $\mathrm{pH}$ of the influent water being too low to sustain effective Mn removal, a new MnOB was commissioned and the $\mathrm{pH}$ of the influent liquor was increased to 6.5, and the HRT was initially maintained as that in phase $\mathrm{C} 1$. However, this did not result in an improved performance, with only $\sim 20 \%$ soluble manganese being removed from the influent liquor during the 28-day test period. The $\mathrm{pH}$ of the effluent liquor varied between 4.5 and 5.1 in phase $\mathrm{C} 2 \mathrm{a}$ (Figure 3). The same MnOB was used in phase $\mathrm{C} 2 \mathrm{~b}$, and the HRT was increased to $\sim 24 \mathrm{~h}$. This resulted in a significant improvement of Mn removal (30-53\%; Figure 2), though concentrations of soluble Mn in the effluent liquor $(70-140 \mu \mathrm{M})$ were still considered to be too high for discharge into the environment. To address this issue, two coupled packed bed bioreactors were tested in phase C3, and the net HRT increased to $\sim 45 \mathrm{~h}$. This resulted in $95 \pm 5 \% \mathrm{Mn}$ removal from the partly processed mine water during the first 44 days of phase $\mathrm{C} 3$, though this subsequently declined (and stabilized) to $\sim 60 \%$. The addition of $100 \mathrm{mg} \mathrm{L}^{-1}$ yeast extract to the influent liquor at day 66 in phase C3 resulted in a rapid improvement in Mn removal (to >99\%), though this was not sustained (Figure 2). pH values of the effluents obtained in phase $\mathrm{C} 3$ were similar to those found in the earlier phases (Figure 3).

The column bioreactor in phase C2 and the first column bioreactor in phase C3 had a thin layer of pale-colored inert gravel placed between two layers of colonized pebbles. This layer was added in order to obtain a visual impression of whether, and how fast, the inert gravel would become colonized by Mn-oxidizing biofilms.

Initially, most Mn removal occurred in the second (newly commissioned) $\mathrm{MnOB}$ in the coupled system, though this quickly changed with the first MnOB assuming a more significant role, particularly when yeast extract was added to the influent liquor (Figure 4).

In addition to removing soluble manganese, the MnOBs were projected to have a potential role in the integrated bioremediation system, further ameliorating the processed water by lowering both the concentrations of dissolved organic components and numbers of bacteria prior to discharge. In the vast majority of tests, electron donors and/or carbon sources for the microorganisms within the MnOBs were only those present in the liquor that drained the sulfidogenic bioreactor (mostly small amounts of glycerol and acetate; [10]). Measurements, taken at the end of phase C3, showed that $\sim 96 \%$ of the DOC (glycerol and yeast extract) used to fuel the integrated system was used in the sulfidogenic bioreactor and that $\sim 74 \%$ of that which remained was catabolized in the MnOB (Table 2). 


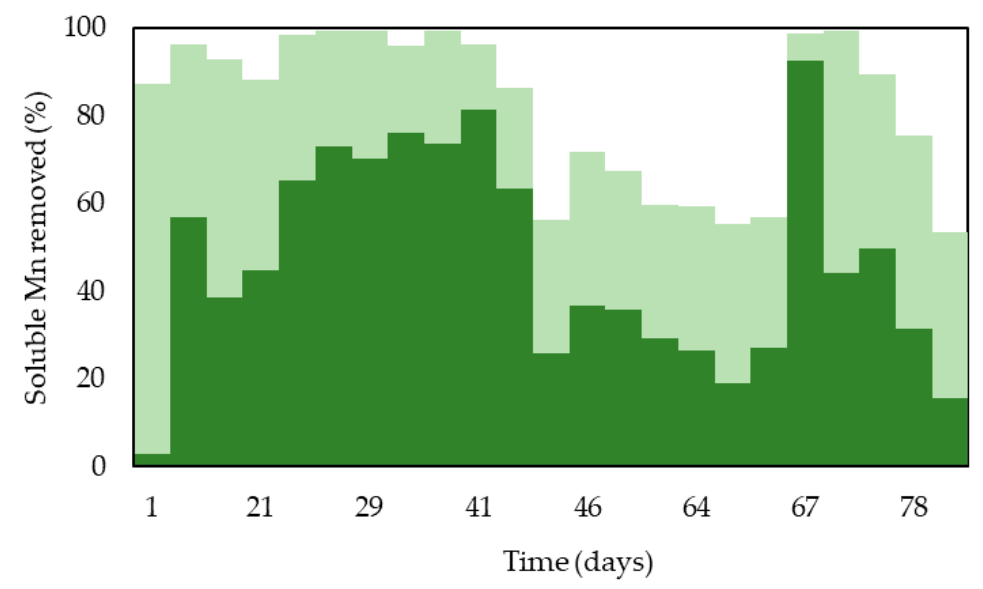

Figure 4. Manganese removed in effluent liquors from the two connected MnOB columns used in phase C3. Key: water draining column 1 (dark green) and water draining column 2 (light green). Yeast extract was added on day 66 (final concentration $100 \mathrm{mg} \mathrm{L}^{-1}$ ).

Table 2. Concentrations of dissolved organic carbon (DOC; $\mathrm{mg} \mathrm{L}^{-1}$ ) in influent and effluent liquors from the sulfidogenic bioreactor and the effluent liquors from the $\mathrm{MnOB}$ as mean values and standard deviations $(n=5)$.

\begin{tabular}{ccc}
\hline & Sulfidogenic Bioreactor & MnOB-Phase C3 \\
\hline Influent & $234 \pm 0.7$ & $9.2 \pm 0.5$ \\
\hline Effluent & $9.2 \pm 0.5$ & $2.4 \pm 0.4$ \\
\hline
\end{tabular}

Numbers of planktonic cells were also generally found to be lower (often much so) in water draining the MnOBs than in influent liquors (Figure 5). Only prokaryotic cells were observed in the planktonic phase of the $\mathrm{MnOB}$, and the identities of these (e.g., whether some were sulfidogens from the anaerobic bioreactor) were not confirmed. It was also noted that surfaces of the uncoated pale pebbles placed in the middle of one of the MnOBs were only slightly darker in color after 138 days of continuous percolation of test liquors than at the start of the experiment.

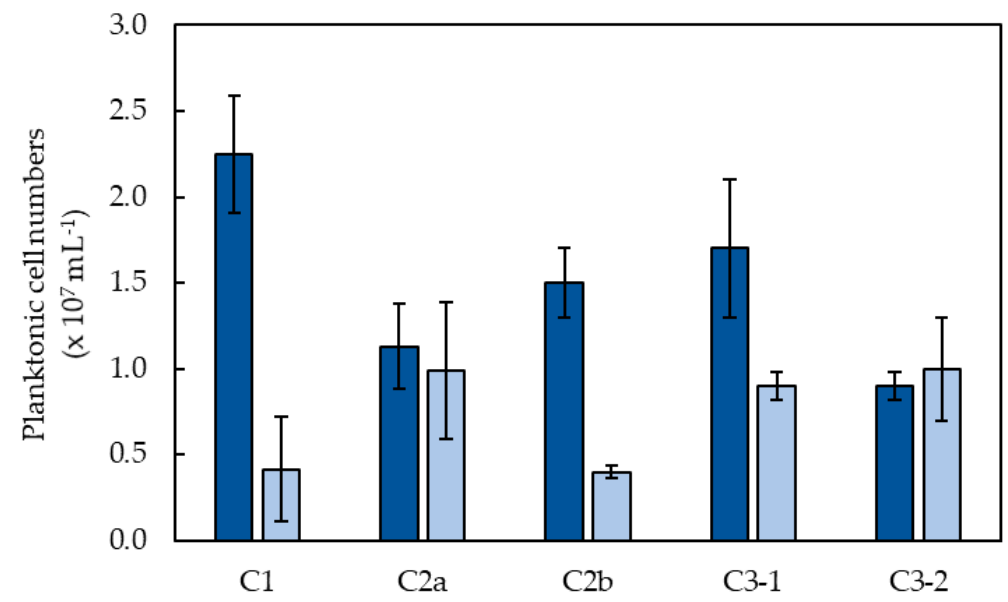

Figure 5. Cell numbers in the feed liquor (dark blue) and effluent liquor (light blue) of the MnOBs. Phases C1 and C2a,b, 1-column system; C3-1 represents column 1 and C3-2 represents column 2 of the in-line 2-column system. The bars depict mean values and the error bars standard deviations $(n=20)$. 


\subsection{Microbial Community Analysis of the Mn (IV) Biofilm-Colonized Pebbles}

The microbial community profile of the black biofilms on pebbles freshly collected from the stream was assessed from clone libraries which were constructed from sequence analysis of bacterial and archaeal $16 \mathrm{~S}$ and eukaryote $18 \mathrm{~S}$ rRNA genes. Figure 6 shows the relative abundance of microbial taxonomy (order level) of the clones obtained from the biofilm-colonized pebbles.

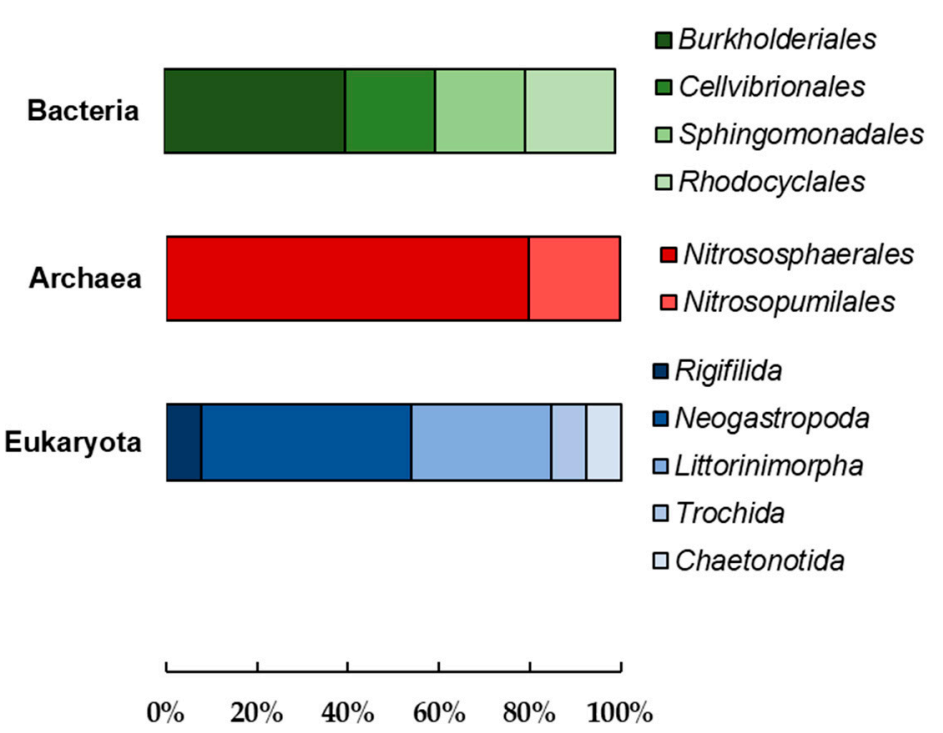

Figure 6. Relative abundance of microbial taxonomy (order) of the clones obtained from Mn (IV) biofilm-colonized pebbles collected from a stream in Snowdonia, UK, based on archaeal and bacterial $16 \mathrm{~S}$ and eukaryote $18 \mathrm{~S}$ rRNA genes.

Within the domain Bacteria, 16S rRNA genes sequences were dominated by Burkholderiales and most of these were related to Leptothrix (L.) discophora (96\% identity), a well-characterized Mn (II)-oxidizer. Archaeal 16S rRNA genes sequences were affiliated with ammonia-oxidizers belonging to phylum Thaumarchaeota and dominated by the orders Nitrososphaerales and Nitrosopumilales. Three of the five taxonomic groups (order level) of eukaryotic $18 \mathrm{~S}$ rRNA genes sequences belonged to phylum Mollusca. No fungi were detected using this technique. Identity of cloned archaeal, bacterial and eukaryotic genes obtained from the biofilm-colonized pebbles are shown in Supplementary Tables S2-S4, respectively. Uncultured clones found in the database were included in cases where clones were distantly related to other known species (identity $<96 \%$ ).

Most of the bacterial clones (Supplementary Table S3) belonged to the phylum Proteobacteria, except the clone MNPBAC19, which appears to belong to the phylum Verrucomicrobia, though the sequence identity match to its nearest known cultivated relative is very low (83\%). The uncultured bacterial clone which closest matched clone MNPBAC19 ( $96 \%$ identity) was obtained from a hyporheic zone of a stream bed in California, which contained iron (hydr)oxide precipitates [17]. Another clone, MNPBAC16, showed a high level of sequence similarity to L. discophora (strain SP-6), a well-documented Mn (II)-oxidizer. Most of eukaryotic clones showed high level of similarity to known organisms that belong to the phylum Mollusca. Clone MnE80 was suggested to belong to Apicomplexa (though only $90 \%$ sequence similarity), which is a large phylum of parasitic alveolates.

T-RFLP analysis carried out on biofilm-colonized pebbles taken directly from the stream in Snowdonia (C0) and at the end of phases $\mathrm{C} 1, \mathrm{C} 2 \mathrm{a}$ and $\mathrm{C} 3$ of the tests with the MnOBs were based on bacterial 16S rRNA genes and eukaryote 18S rRNA genes. The data revealed a large number of T-RF peaks in all samples analyzed. Figure 7 shows how T-RFLP bacterial profiles on the biofilm-colonized pebbles varied amongst MnOBs. Many T-RFs of the same length were found in all samples. The $217 \mathrm{nt} \mathrm{T-RF}$ showed high relative abundance in most samples, accounting overall for $\sim 17 \%$ of the total bacterial population 
in phases C0, C2a and C3. The exception was phase C1, where a 214 nt T-RF was more dominant, accounting for $21 \%$ of the summated T-RFs. The 223 nt T-RF matched the theoretical T-RF of the clones which were closely related to L. discophora. Overall, its relative abundance in the bacterial community of the colonized pebbles was $~ 5 \%$; however, more than one organism shared the same T-RF length (Supplementary Table S3) and therefore it cannot be assumed that this T-RF corresponded to only L. discophora.

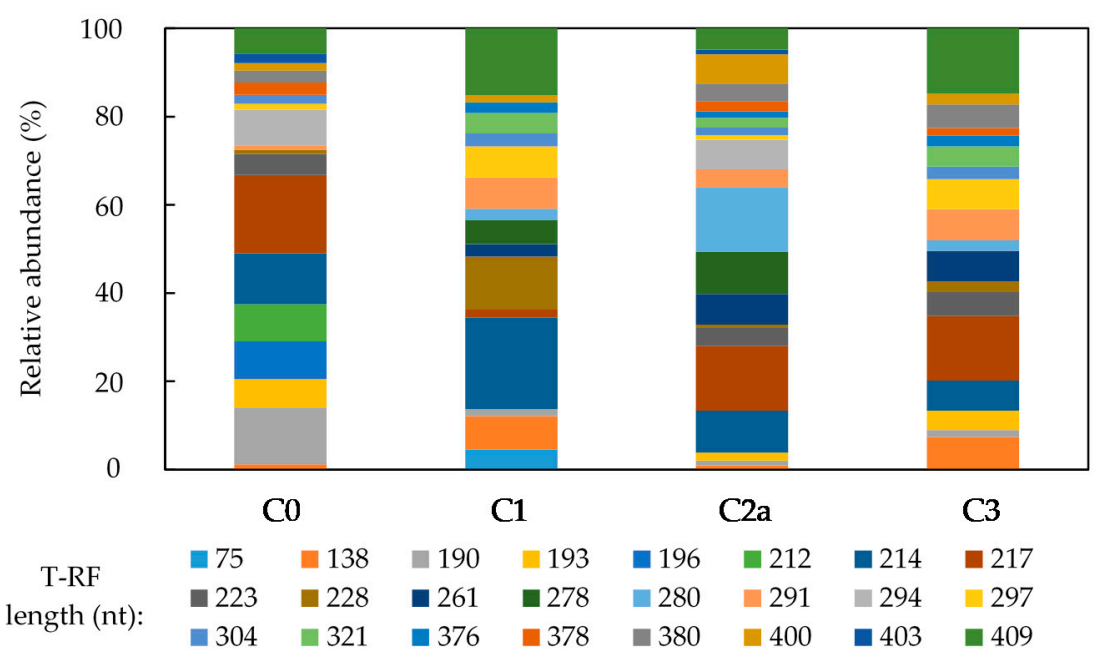

Figure 7. Terminal restriction enzyme fragment length polymorphism (T-RFLP) analysis (HaeIII digests) of amplified 16S rRNA bacterial genes from the biofilm-colonized pebbles collected from the stream (C0) and at different phases (C1, C2a and C3) of operating MnOBs. The T-RFs are stacked upwards in each column in increasing fragment lengths.

Supplementary Figure S6 shows how T-RFLP profiles of eukaryotes on the biofilmcolonized pebbles varied amongst MnOBs. Major changes were observed in the eukaryotic populations in the experiment. The $280 \mathrm{nt}$ T-RF was dominant in all phases of the MnOB, accounting for $\sim 72 \%$ of the eukaryotic population in phase C3; however, this same T-RF was shared with several organisms listed in Supplementary Table S4.

\subsection{Characterization of a Mn (II)-Oxidizing Fungal Isolate}

A brown/black-colored fungal isolate, coded MnI1, was obtained on solid medium that had been inoculated with a biofilm from a pebble removed from the MnOB after 6 days of phase $\mathrm{C} 2 \mathrm{~b}$. Colonies were evident on solid medium within 5 days and showed the characteristic brown/black color of the mycelia (Supplementary Figure S5a). The colonies had rhizoidal morphologies and filiform margins, with vegetative and aerial/reproductive mycelia, characteristic of filamentous fungus. Colonies adhered firmly to the solid medium and presented low emulsification in water. Colonies of isolate MnI1 grown on Mn-free solid medium had nonpigmented hyphae (Supplementary Figure S5b). Even though the fungal mycelia on Mn-free plates were also dark-colored in the center of the colonies, the difference between pigmentation of the colonies on Mn-containing and Mn-free plates was clearly noticeable, suggesting that brown/black-colored insoluble Mn (IV) oxides were deposited onto fungal mycelium on plates containing soluble manganese. Micrographic images of the isolate growing on solid medium in presence and absence of Mn (II) showed that the isolate formed nonseptate hyphae and putative manganese oxides were found as particulate materials that were associated with the fungal hyphae (Supplementary Figure S7a). Microscopic examination of the pigmented centers of these colonies did not reveal the presence of particulate materials, as found on Mn (II)-containing plates (Supplementary Figure S7b).

Phylogenetic analysis revealed that isolate MnI1 belongs to the Ascomycota phylum and clusters with members of the order Pleosporales, class Dothideomycetes. The 18S rRNA genes sequence from MnI1 was closely related ( $98 \%$ gene similarity) to those from Ulospora bilgramii and several other species. The phylogenetic tree (Figure 8) showed 
MnI1 as a single member of a clade forming a branch with low bootstrap values of $47 \%$, supporting the monophily of the clade. Based on these findings, it appears that this fungal species has not been previously described.

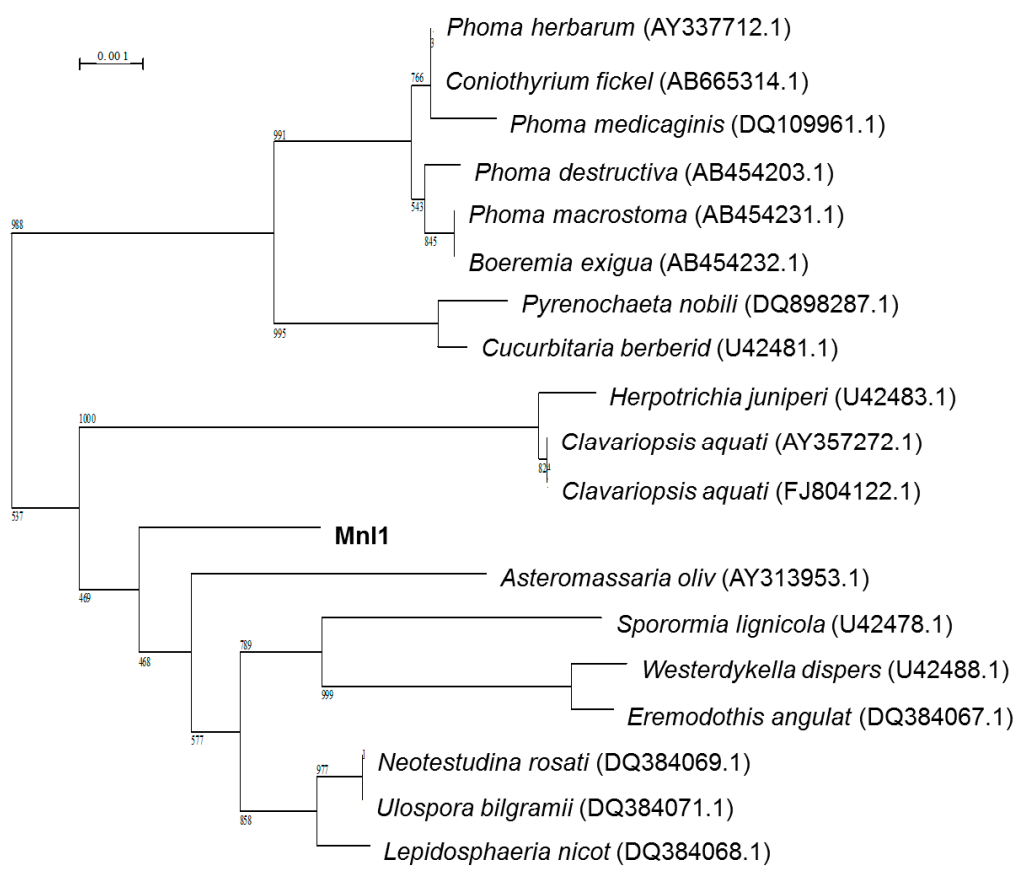

Figure 8. Phylogenetic tree showing the relationship of the fungal isolate MnI1 to other microorganisms based on 18S rRNA sequence homology (values in brackets are NCBI accession numbers). Scale bar is number of nucleotides substituted per base pair. Bootstrap values are given at the respective nodes. The tree was rooted with the $18 \mathrm{~S}$ rRNA gene sequence of Saccharomyces cerevisiae (J01353.1).

Oxidation of Mn (II) by isolate MnI1 was tested in liquid media at initial pH 6.5 and $25{ }^{\circ} \mathrm{C}$, and results are shown in Figure 9. Concentrations of soluble manganese in noninoculated control remained constant throughout the experiment, whereas in the inoculated flasks, concentrations of soluble Mn decreased gradually, from 450 to $97 \mu \mathrm{M}$ after 13 days. Parallel trends were observed with $\mathrm{pH}$ values. The final $\mathrm{pH}$ of noninoculated control was 6.5 , whereas the final $\mathrm{pH}$ of the inoculated flasks was $\sim 4.0$.

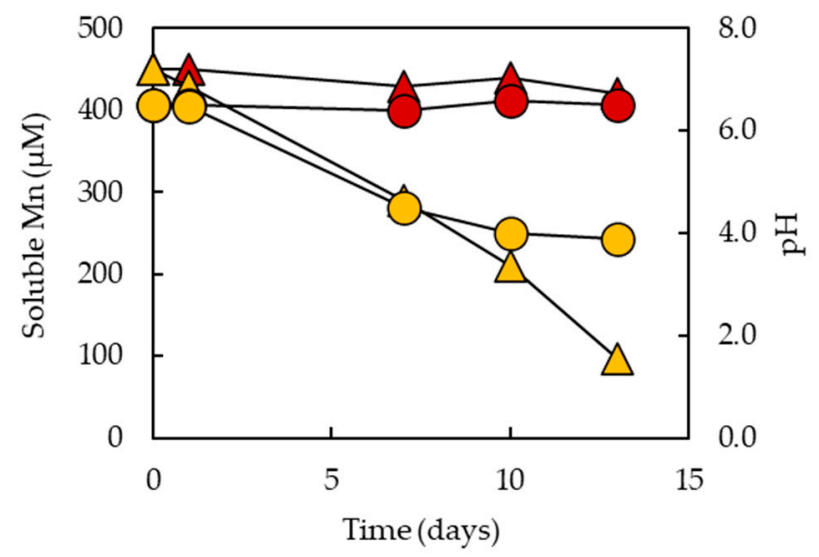

Figure 9. Changes in soluble manganese concentrations $(\Delta, \mathbf{\Delta})$ and $\mathrm{pH}(\bullet, \bullet)$ in shake flasks cultures inoculated with isolate $\operatorname{MnI} 1(\Delta, \bullet)$ and noninoculated controls $(\boldsymbol{\Delta}, \bullet)$ with isolate MnI1. The experiment was carried out in duplicate and different values between replicates are occluded by the symbols. 
Isolate MnI1 was able to grow between 15 and $30^{\circ} \mathrm{C}$ and appeared (from visual inspection of cultures) to grow optimally at $25^{\circ} \mathrm{C}$. No growth was observed at $45^{\circ} \mathrm{C}$. The isolate formed dark brown/black-colored mycelia in liquid media at all temperatures where growth was observed. Growth was observed over a wide $\mathrm{pH}$ range (4.0-8.0) and was more pronounced between $\mathrm{pH} 4.0$ and $\mathrm{pH} 6.5$, at which the spherical mycelial growths in the flasks were uniformly pigmented dark brown/black. Growth was less evident at higher $\mathrm{pH}$ (7.0 and 8.0) and the fungal mycelium was brown/black-colored in the center of the colonies but the peripheries were nonpigmented, and at $\mathrm{pH} 8.0$ entire mycelium was white in color. Isolate MnI1 grew on a wide range of organic compounds (Supplementary Table S5), including hexoses (fructose and mannose), pentoses (ribose, arabinose, xylose), and methyl pentoses (rhamnose), some disaccharides (sucrose, maltose, lactose) and alcohols (mannitol, glycerol, ethanol and benzyl alcohol), though not on the amino acids tested (alanine, glycine, leucine).

\section{Discussion}

Manganese is often the most recalcitrant transition metal found in elevated concentrations in mine drainage waters in terms of how amenable it is to be removed by chemical means. Thermodynamically, Mn (II) should oxidize spontaneously to Mn (IV) in aerated, neutral $\mathrm{pH}$ waters, but the activation energy required is relatively high, which impedes the reaction [18]. This barrier can be overcome by Mn (II)-oxidizing microorganisms that catalyze the oxidation of divalent, soluble Mn (II) to insoluble Mn oxides. Other studies have reported biological manganese oxidation at low $\mathrm{pH}$ (5.5) in a manganese deposit influenced by metal-rich groundwater [6] and in low $\mathrm{pH}$ uranium-contaminated groundwater and soil material from a uranium mine area in Germany [5].

Manganese (II) can, however, also be removed from solution by adsorption onto solid phase Mn (IV) oxides [1] without being oxidized. Manganese oxides are known for their ability to absorb metals and for their cation exchange capacities [19]. The former derives from negative charges of Mn (IV) oxides due to the presence of some Mn (III) or vacant sites within the mineral lattice structure [3]. Consequently, cationic transition metal as well as alkali and alkaline earth metals can be adsorbed to neutralize this negative charge, though the polarity of the charge borne by manganese (IV) oxides is pH-dependent. Mariner et al. [11] determined the point of zero charge $\left(\mathrm{pH}_{\mathrm{PZC}}\right)$, i.e., the $\mathrm{pH}$ above which the Mn (IV) oxides is net negatively charged and below which it is net positively charged, of a similar material to that used in the present study, to be 5.5. Mineralogical analysis of the biofilms was not performed, though previous work using a similar system identified the Mn (IV) mineral phase as birnessite [11], which is the most common Mn (IV) bio-oxide in aquatic environments [3]. Solution $\mathrm{pH}$ would therefore have had an important influence on both adsorption and (microbial) oxidation on $\mathrm{Mn}$.

The oxidation of Mn (II) and formation of insoluble Mn (IV) is a proton-generating reaction:

$$
\begin{gathered}
\mathrm{Mn}(\mathrm{II}) \rightarrow \mathrm{Mn}(\mathrm{III})+\mathrm{e}^{-} \\
\mathrm{Mn}(\mathrm{III})+2 \mathrm{H}_{2} \mathrm{O} \rightarrow \mathrm{MnO}(\mathrm{OH})+3 \mathrm{H}^{+} \\
\mathrm{MnO}(\mathrm{OH}) \rightarrow \mathrm{MnO}_{2}+\mathrm{H}^{+}+\mathrm{e}^{-}
\end{gathered}
$$

In theory, oxidation and precipitation of $150 \mu \mathrm{M}$ Mn (II) should generate $300 \mu \mathrm{M}$ proton acidity (equivalent to $\mathrm{pH} 3.5$ if generated in pure water) and it is interesting that the $\mathrm{pH}$ of the influent liquor (5.0 or 6.5) had little impact on that of the effluent generated.

The Mn (IV) biofilm-colonized pebbles used in the bioreactors removed soluble Mn from the partly processed synthetic mine water very effectively at the start of phase C1, but this was not sustained in the longer term. This indicated that the initial removal of Mn (II) was due to adsorption onto the Mn (IV) biofilms, and that once adsorption sites had been more or less saturated the rate-limiting factor was likely to be the subsequent oxidation of immobilized Mn which would have generated additional Mn (IV) (hydroxy)oxides, thereby allowing the process to perpetuate. Increasing the $\mathrm{pH}$ of the feed liquor from 5.0 to 
6.5 in phase $\mathrm{C} 2 \mathrm{a}$ (using a different $\mathrm{MnOB}$ ) did not improve immobilization of $\mathrm{Mn}$, though combining this with a larger HRT did (phase C2b). Increasing the HRT still further in phase C3 and using a two-stage bioreactor system (one of which was again newly commissioned) resulted in a marked improvement in performance, with $90-100 \%$ of Mn removed over the first 44 days of operation. Although this subsequently declined to $\sim 60 \% \mathrm{Mn}$ removal, a oneoff addition of a small amount of yeast extract brought about a rapid (though short-lived) improvement in the performance of the coupled MnOBs, with 99\% Mn being removed from solution.

The latter result suggested that the rate-limiting factor in determining how effective the bioreactors were in the longer-term was biological (the oxidation of Mn (II) to Mn (IV)) rather than chemical (adsorption of Mn (II)). It also highlighted that: (i) manganese oxidation appeared to be catalyzed by heterotrophic rather than autotrophic microorganisms; (ii) organic materials in the influent liquor were either present in insufficient concentrations or not readily metabolized by Mn-oxidizing populations in the MnOBs. Considering the latter, the average DOC concentration in the influent liquor was $9.10 \mathrm{mg} \mathrm{L}^{-1}$, and Santos and Johnson [10] previously identified that some of this DOC was glycerol and acetate, present in equivalent concentrations of 3.25 and $2.40 \mathrm{mg} \mathrm{C} \mathrm{L}^{-1}$, respectively. Assuming that, as is the case for glucose, yeast extract contains $\sim 40 \%$ carbon, the addition of $100 \mathrm{mg}$ of yeast extract to each liter of influent liquor would have increased its DOC content by $>500 \%$ (to $\sim 49 \mathrm{mg} \mathrm{L}^{-1}$ ). This lends support to the hypothesis that concentrations of metabolizable organic materials in nonamended influent liquors were insufficient to support effective microbial growth and Mn (II) oxidation. Hydrodynamically, the biofilm formation and adhesion on the Mn (IV)-coated pebbles may possibly be improved by increasing fluid shear rate on the support surface as demonstrated by Rusconi et al. [20]. The low superficial liquid velocity, due to relatively slow flow rates, might possibly also explain why there was limited, if any, formation of Mn (IV) biofilms on the gravel placed into one of the MnOBs, after 138 days.

Two microorganisms present in the biofilm community were identified as Mn (II)oxidizers. One was the bacterium $L$. discophora, which was identified both in clone libraries and by T-RFLP analysis (by calculating theoretical T-RF length). This bacterium is a strictly aerobic Gram-negative heterotroph, reported to grow on substrates such as peptone, yeast extract, glucose, pyruvate, malate but not on lactate, citrate and acetate, and to oxidize Mn (II) between pH 6 and pH 8 [21]. The other was a Mn (II)-oxidizing fungus, which was isolated from the surface of colonized pebbles from the MnOB. T-RFLP analysis of $18 \mathrm{~S}$ rRNA genes (HaeIII digests) amplified from the black biofilms on the fresh pebbles and in those coating the MnOBs throughout the experiment, showed a high relative abundance of a $280 \mathrm{nt}$ T-RF, most notably in phase C3, which corresponded to the theoretical HaeIII digest of the 18S rRNA gene of the isolate, though some other eukaryotic clones obtained from the biofilm also had the same T-RF length as the fungal strain. Isolate MnI1 belongs to the order Pleosporales (Ascomycota phylum) and appears to be a novel species. Several Mn (II)-oxidizers have previously been described within this order [11,22-24]. Isolate MnI1 catalyzed the removal of soluble manganese from liquid media, and accumulated brown/black-colored precipitates (presumably of Mn (IV)) on its mycelia when grown on Mn-containing plates. The centers of the fungal colonies (though not the filamentous outgrowths) on Mn-free plates also had a dark brown pigmentation, which was possibly due to the smaller amount of Mn (II) $(18 \mu \mathrm{M})$ present in the trace elements solution used in the basic medium. Physiological tests carried out in Mn-containing liquid media showed that isolate MnI1 grew over a relatively wide range of $\mathrm{pH}$ (4.0-8.0), though the final culture $\mathrm{pH}$ values were always significantly lower than at the start, and typically $\sim \mathrm{pH} 4$. Manganese oxidation was not measured in the variable $\mathrm{pH}$ experiment with this isolate, though other experiments confirmed that this isolate oxidized Mn (II) and precipitated Mn (IV). Abiotic Mn oxidation requires $\mathrm{pH}$ values above 8, and therefore chemical oxidation was considered unlikely in the variable $\mathrm{pH}$ experiment. Isolate $\mathrm{MnI} 1$ also grew on a wide range of organic compounds, including glycerol and acetate, substrates identified in the 
influent liquors. This suggests that amendment with a more cost-effective substrate than yeast extract might be suitable to promote and sustain microbially-catalyzed Mn removal in the bioreactors.

In the current study, the MnOBs were commissioned and used as part of a more complex integrated system for removing (and recycling) different metals from a specific mine water, though the flexible modular design would have more generic application for mitigating contaminated metal-rich water bodies. Their primary role was to lower concentrations of soluble Mn to below prescribed levels for discharging into the wider environment. Regulation $\mathrm{N}^{\circ} 430 / 2011$ set by the National Environmental Council (CONAMA, Brazil) [25] has delineated a maximum contaminant level for industrial effluent discharge for manganese of $1.0 \mathrm{mg} \mathrm{L}^{-1}$, which means that, for this particular case, at least $90 \%$ of the manganese present in the Mn-containing mine water would need to be removed prior to discharge, and this was achieved when the MnOBs were performing effectively. These bioreactors also had a secondary role in improving water quality on both lowering the DOC of the processed water and moderating numbers of bacteria. There was good evidence to support the former role, with the final effluents containing $<3.0 \mathrm{mg} \mathrm{DOC} \mathrm{L}^{-1}$. Concentrations of DOC found in rivers can vary from 1.0 (e.g., mountainous Alpine environments) to $20 \mathrm{mg} \mathrm{L}^{-1}$ (e.g., taiga rivers), and a world DOC average for rivers was established as $5.75 \mathrm{mg} \mathrm{L}^{-1}$ [26], which is above that of the processed synthetic mine water generated in the present study. Addition of organic substrates to improve Mn removal in the MnOBs could lead to an increase in the DOC of processed liquors, though most of the added DOC would be anticipated, in a controlled system, to be metabolized within the bioreactors themselves. Numbers of planktonic cells in the effluent liquor from the $\mathrm{MnOB}$ were generally lower than those in the feed liquors, possibly due to microorganisms becoming attached to the pebbles. What percentage of these were viable cells is unknown, and it would be anticipated that many of the anaerobic bacteria entering the $\mathrm{MnOBs}$ in liquor generated in the upstream sulfidogenic bioreactor would be killed in the aerated reactors.

\section{Conclusions}

Removal of soluble Mn (II) present in partly processed synthetic mine water was effectively removed in column bioreactors packed with pebbles coated with Mn (IV) biofilms by a combination of chemical adsorption and microbial oxidation. The Mn (II)-oxidizing microflora were predominantly heterotrophic, and provision of small amounts of additional organic substrates appeared to be required to sustain their activities and to effectively remove manganese. Under optimized conditions, $>99 \%$ of Mn removal was obtained, lowering concentrations of soluble $\mathrm{Mn}$ to below regulatory discharge levels. Microbiological remediation greatly reduced the requirement for large amounts of alkali addition associated with chemical mitigation of Mn-rich waters. Future work should consider the effect of both continuous input of organic carbon and fluid shear stress on biofilm growth and manganese removal. At least two species of Mn-oxidizing microorganisms were identified-the bacterium L. discophora and a novel fungus that was isolated and characterized in vitro.

Supplementary Materials: The following are available online at https:/ / www.mdpi.com/article/10 .3390/app11094287/s1, Figure S1: Image of the Mn (IV)-coated pebbles collected from a catchment stream in North Wales, UK, Figure S2: Summary of the integrated system protocol, Figure S3: Fixed bed bioreactor packed with Mn (IV) biofilm-colonized pebbles, Figure S4: Schematic representation of the in-line 2-column Mn (II)-oxidizing bioreactor, Figure S5: Images of isolate MnI1 grown on solid media, Figure S6: Terminal restriction enzyme fragment length polymorphism (T-RFLP) analysis (HaeIII digests) of amplified 18S rRNA eukaryotic genes from the biofilm-colonized pebbles, Figure S7: Micrographs of the isolated MnI1, Table S1: Summary of the forward and reverse primer sequences used in this study, Table S2: Identity of cloned archaeal genes (16S rRNA gene) obtained from the biofilm-colonized pebbles collected from the stream in Snowdonia, Table S3: Identity of cloned bacterial genes (16S rRNA gene) obtained from the biofilm-colonized pebbles collected from the stream in Snowdonia, Table S4: Identity of cloned eukaryotic genes (18S rRNA gene) obtained 
from the biofilm-colonized pebbles collected from the stream in Snowdonia, Table S5: Utilization of organic substrates by MnI1.

Author Contributions: Conceptualization, D.B.J.; methodology, D.B.J. and A.L.S.; investigation, A.L.S.; data curation, A.L.S.; writing—original draft preparation, A.L.S.; writing—review and editing, D.B.J.; visualization, A.L.S.; supervision, D.B.J.; funding acquisition, A.L.S. All authors have read and agreed to the published version of the manuscript.

Funding: A.L.S. is grateful to the National Council for Scientific and Technological Development (CNPq-Brazil) for provision of a research studentship (Grant No. 248994/2013-1).

Data Availability Statement: Data not available in publicly archived datasets.

Conflicts of Interest: The authors declare no conflict of interest.

\section{References}

1. Ehrlich, H.L.; Newman, D.K. Geomicrobiology of Manganese. In Geomicrobiology, 5th ed.; Ehrlich, H.L., Newman, D.K., Eds.; CRC Press: Boca Raton, FL, USA, 2008; pp. 347-420.

2. Vanẏsek, P. Electrochemical Series. In Handbook of Chemistry and Physics, 93th ed.; Haynes, W.M., Ed.; CRC Press: Boca Raton, FL, USA, 2012; pp. 5-80.

3. Tebo, B.M.; Bargar, J.R.; Clement, B.G.; Dick, G.J.; Murray, K.J.; Parker, D.; Verity, R.; Webb, S.M. Biogenic Manganese Oxides: Properties and Mechanisms of Formation. Annu. Rev. Earth Planet. Sci. 2004, 32, 287-328. [CrossRef]

4. Yu, H.; Leadbetter, J.R. Bacterial chemolithoautotrophy via manganese oxidation. Nat. Res. 2020, 583, 453-465. [CrossRef] [PubMed]

5. Akob, D.M.; Bohu, T.; Beyer, A.; Schäffner, F.; Händel, M.; Johnson, C.A. Identification of Mn(II)-oxidizing bacteria from a low-pH contaminated former uranium mine. Appl. Environ. Microbiol. 2014, 80, 5086-5097. [CrossRef] [PubMed]

6. Bohu, T.; Akob, D.M.; Abratis, M.; Lazar, C.S.; Kusel, K. Biological low-pH Mn(II) oxidation in a manganese deposit influenced by metal-rich groundwater. Appl. Environ. Microbiol. 2016, 82, 3009-3021. [CrossRef] [PubMed]

7. Hallberg, K.B.; Johnson, D.B. Biological manganese removal from acid mine drainage in constructed wetlands and prototype bioreactors. Sci. Total Environ. 2005, 338, 115-124. [CrossRef] [PubMed]

8. Monhemius, A.J. Precipitation diagrams for metal hydroxides, sulfides, arsenates and phosphates. Trans. Inst. Min. Metall. 1977, 86, C202-C206.

9. Jacob, J.; Raignault, I.; Battaglia-Brunet, F.; Mailhan-Muxi, C.; Engevin, J.; Djemil, M. Biological Manganese Removal from Mine Drainage in a Fixed Bed Bioreactor at Pilot Scale. In Proceedings of the 13th International Conference on Mine Closure, Perth, Australia, 3-5 September 2019; pp. 911-920.

10. Santos, A.L.; Johnson, D.B. The effects of temperature and $\mathrm{pH}$ on the kinetics of an acidophilic sulfidogenic bioreactor and indigenous microbial communities. Hydrometallurgy 2017, 168, 116-120. [CrossRef]

11. Mariner, R.; Johnson, D.B.; Hallberg, K.B. Characterisation of an attenuation system for the remediation of Mn (II) contaminated waters. Hydrometallurgy 2008, 94, 100-104. [CrossRef]

12. Lane, D.J. 16S/23S rRNA Sequencing. In Nucleic Acid Techniques in Bacterial Systematics; Stackebrandt, E., Goodfellow, M., Eds.; John Wiley \& Sons: Chichester, UK, 1991; pp. 115-175.

13. Kay, C.M.; Rowe, O.F.; Rocchetti, L.; Coupland, K.; Hallberg, K.B.; Johnson, D.B. Evolution of microbial "streamer" growths in an acidic metal-contaminated stream draining an abandoned underground copper mine. Life 2013, 3, 189-211. [CrossRef] [PubMed]

14. Falagán, C.; Sánchez-Espana, J.; Johnson, D.B. New insights into the biogeochemistry of extremely acidic environments revealed by a combined cultivation-based and culture-independent study of two stratified pit lakes. FEMS Microbiol. Ecol. 2014, 87, 231-243. [CrossRef] [PubMed]

15. Nancucheo, I.; Rowe, O.F.; Hedrich, S.; Johnson, D.B. Solid and liquid media for isolating and cultivating acidophilic and acid-tolerant sulfate-reducing bacteria. FEMS Microbiol. Lett. 2016, 363, 1-6. [CrossRef] [PubMed]

16. Mariner, R.; Johnson, D.B.; Hallberg, K.B. Development of a novel biological system for removing manganese from contaminated waters. Adv. Mater. Res. 2007, 20-21, 267-270. [CrossRef]

17. Duckworth, O.W.; Holmström, S.J.M.; Peña, J.; Sposito, G. Biogeochemistry of iron oxidation in a circum-neutral freshwater habitat. Chem. Geol. 2009, 260, 149-158. [CrossRef]

18. Stumm, W.; Morgan, J.J. Aquatic Chemistry: An Introduction Emphasizing Chemical Equilibria in Natural Waters; Wiley Interscience: New York, NY, USA, 1981; p. 583.

19. Ehrlich, H.L. Geomicrobiology, 4th ed.; Marcel Dekker: New York, NY, USA, 2002; p. 800.

20. Rusconi, R.; Guasto, J.S.; Stocker, R. Bacterial transport suppressed by fluid shear. Nat. Phys. 2014, 10, 212-217. [CrossRef]

21. Adams, L.F.; Ghiorse, W.C. Physiology and ultrastructure of Leptothrix discophora SS-I*. Arch. Microbiol. 1986, 145, 126-135. [CrossRef]

22. Miyata, N.; Maruo, K.; Tani, Y.; Tsuno, H.; Seyama, H.; Soma, M.; Iwahori, K. Production of biogenic manganese oxides by anamorphic Ascomycete fungi isolated from streambed pebbles. J. Geomicrobiol. 2006, 23, 63-73. [CrossRef] 
23. Santelli, C.M.; Pfister, D.H.; Lazarus, D.; Sun, L.; Burgos, W.D.; Hansel, C.M. Promotion of Mn(II) oxidation and remediation of coal mine drainage in passive treatment systems by diverse fungal and bacterial communities. Appl. Environ. Microbiol. 2010, 76, 4871-4875. [CrossRef] [PubMed]

24. Sasaki, K.; Konno, H.; Endo, M.; Takano, K. Removal of Mn(II) ions from aqueous neutral media by manganese-oxidizing fungus in the presence of carbon fiber. Biotechnol. Bioeng. 2004, 85, 489-496. [CrossRef] [PubMed]

25. Industrial Effluent Discharge Act 2011 (No. 430/2011) Brasília: Conselho Nacional Do Meio Ambiente. Available online: http: / / www.mma.gov.br/port/conama/legiabre.cfm?codlegi=646 (accessed on 21 January 2015).

26. Meybeck, M. Carbon, nitrogen, and phosphorus transport by world rivers. Am. J. Sci. 1982, 282, 401-450. [CrossRef] 